\title{
Types and selection of valves for transcatheter aortic valve implantation
}

\author{
(1) Jozica Šikić ${ }^{1,2}$, \\ (D) Petar Bešlić1* \\ 'University Hospital "Sveti \\ Duh", Zagreb, Croatia \\ 2University of Zagreb, School \\ of Medicine, Zagreb, Croatia
}

KEYWORDS: valvular heart disease, severe aortic stenosis, transcatheter aortic valve implantation. CITATION: Cardiol Croat. 2021;16(9-10):300. | https://doi.org/10.15836/ccar2021.300

*ADDRESS FOR CORRESPONDENCE: Petar Bešlić, Klinička bolnica "Sveti Duh“, Sv. Duh 64, HR-10000 Zagreb, Croatia. / Phone: +385-92-244-2253 / E-mail: petar.beslic@hotmail.com

ORCID: Jozica Šikić, https://orcid.org/0000-0003-4488-0559 • Petar Bešlić, https://orcid.org/0000-0001-6141-6526

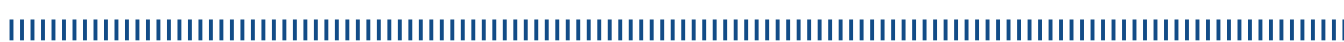

Since its introduction at the turn of the century, transcatheter aortic valve implantation (TAVI) has created a revolution in the treatment of patients with symptomatic aortic valve stenosis. In the early days of TAVI we used only two different devices with limited sizes and access options, but now we have a wide range of commercially available transcatheter aortic heart valves. These valves differ significantly in design, configuration, and mechanism. They may be balloon-expandable, self-expanding, or mechanically expanded, and bioprosthetic leaflets may be intra- or supra-annular. Frame cell size and configuration, frame height, size range, and the design and profile of the delivery system and access sheath all differ. ${ }^{1}$ Although many patients are often successfully treated with any of variety of valves, yet there are nuances that may lead to one valve being more suitable than another in a specific patient and anatomic subgroups, like younger patients, those with degenerative surgical bioprostheses (valvein-valve TAVI), bicuspid aortic valves, severe left ventricular outflow tract and annular calcification or coronary artery disease.
RECEIVED:

July 31, 2021

ACCEPTED:

August 5, 2021

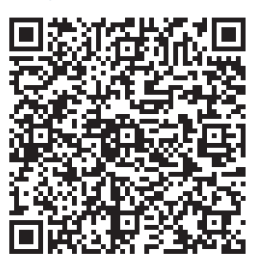

$\square$ Cardiologia Croatica 2021;16(9-10):300.
5. kongres Radne skupine za bolesti srčanih zalistaka Hrvatskoga kardiološkog društva s međunarodnim sudjelovanjem $5^{\text {th }}$ Congress of the Working Group on Valvular Diseases of the Croatian Cardiac Society with international participation September 2-4, 2021, Zagreb, Croatia 